\title{
'Desecrators' and 'Necromancers': Black American Writers and Critics in the Nineteen-Sixties and the Third World Perspective
}

\section{By Sigmund Ro}

University of Trondheim

To presume to make definitive judgements about the black American literary nationalism of the nineteen-sixties is foolhardy. Its critical and creative fruits present themselves to us as shifting and unruly strains in a still ongoing process. The student of contemporary Afro-American writing finds himself wandering, dazed, in a hothouse of artistic growth whose sheer diversity and contrary pulls defy any attempt at confident generalizing.

One possible general perspective on this »neo-black « creativity, however, is to view the new generation as engaged in an enterprise parallel to that of post-war African and Caribbean writers: „a type of reconnaissance in the formation of a new imaginative world free from the proscriptions of a racist West. « To see literary expression by black Americans in the sixties as a collective effort to create such a new imaginative world is to enter into its innermost spirit. After what was felt to be the bankruptcy of the image that had controlled the first post-war decade - »the Negro as America's metaphor " - this was the revisionist task demanded of a new literary generation: the formation of a new imaginative order purged of oppressive white influence. In realizing this aim, as the decade progressed, black artists in the United States increasingly saw themselves as engaged in an enterprise parallel to what Samuel Allen describes as the task undertaken by Senghor's group in Paris: »to cast off the cultural imprint of colonial Europe. $\varkappa^{2}$ After 1965 - the year of

- crossroads for so many - the colonial metaphor to a large extent ruled the new black literary thought. It was these changes of consciousness and sensibility, as they were reflected in the highly publicized real-life models of Malcolm X, Eldridge Cleaver, Frantz Fanon, Stokeley Carmichael, LeRoi Jones/Amiri Baraka, H. Rap Brown, Julius Lester, George Jackson, Angela Davis and others, that underlay the thrust to 
establish a new imaginative island which, though in the West, would not be of it.

The formation of such a literary sensibility could not take place in a vacuum, however. Given the recalcitrance of historical experience, it was inevitable that the redefinition of black American identity as a diasporic identity and of black American art in an African or Third World context should find its specific expression within already familiar categories in New World black writing. Observing the Afro-American literary scene of the sixties with the benefit of hindsight, one discerns this interaction between the new Third World vistas and traditional black American patterns at work in the transformation of the classic twin impulse in black American letters towards rage and celebration, traditionally expressed in protest writing and in literary tributes to the Negro's redemptive heritage in the American »dusty desert of dollars and smartness (W.E.B. DuBois in The Souls of Black Folk). No longer did black poets, dramatists, and prose writers conceive of themselves within the time-honored roles of angry pleaders for Negro rights or celebrators of the quintessential Americanness of the racial experience. In their efforts to de-Westernize black art, this was the new and revised duality: a fiery wrath and, on the other hand, a proud exaltation of an exclusive blackness, a passionate urge to »murder and create. «. The result was to recast the black writer in the double role of - in Larry Neal's and Ishmael Reed's African-American terminology — »desecrator» and »necromancer.«

What the present essay proposes to deal with, then, is this distinctive design in the new black writing of a metamorphosis of the traditional pattern of rage and celebration under the impact of a compelling desire to repudiate the aesthetic derived from sthe-Negro-as-America's-metaphor by detaching the black man from the West and bringing him into the orbit of the post-Western humanism being forged in the new historical crucible of an Afro-centric Third World. However individual the responses to the meaning and relevance of Africa, the call which issued from the new writing was for a dissociation of black America from the cultures of the First and Second Worlds and a reinterpretation of the racial experience.

In this yearning to attach black America to a cultural matrix outside the Euro-American tradition so as to join in the adventure of shaping a superior post-western humanism, the profoundly idealistic spirit at the core of the massive release of expressive energy in the latter half of the decade is also reflected. This aspect was often obscured or distorted by the fears of the white majority at the sight of violent uprisings and the 
tendency of the media to project negative images of the black revolution as wanton destruction. The constructive challenge before the black writer was no longer felt to be that expressed by Baldwin in 1950 in his solitary abode in the heart of a continental Europe still strewn with the wreckage of war: the redemptive grafting of the Negro's experience on to the Western tree. A literary generation later, the task was that of grafting the black American's soul, as seen through the vistas of nearly four hundred years, on to the tree of his African brother's negritude in a shared synthesis of consciousness and sensibility. Only in such a synthesis, forged on the Third World frontier whose vanguard is modern Africa, was seen to lie the possibility of a new humanism, indispensable not only to the survival and self-discovery of the black American, but to the survival and advancement of all human culture in the embattled global village which is the modern world. The judgements of such a herculean effort will vary. But in judging its success, one should not forget that to set impossibly high goals for the race's literary craftsmen has always been part of the tradition of black American letters. In every generation, demands have been made of it which have imposed burdens not ordinarily imposed on any art.

Such, then, was the new literarily productive sensibility of the second post-war decade, born of the encounter between new geopolitical and historical circumstances and patterns of expression rooted in the soil and experience of the racial group in America. It is this sensibility that we must now reconnoitre, bearing in mind that what we can hope to discover is no more than the disclosure of an inner synonymity of perspective in the midst of contemporary flux.

As the fifties were drawing to a close, a new cultural force, symbolized by the proclamation of Nkruma's free Ghana in 1957, appeared on the scene to challenge the consensus view of the Negro's essential Americanness and of his artistic achievement as a contribution to the joint carpus of American cultural expression. Africa was rapidly becoming a visible presence to a reluctant literary establishment still presided over by $\mathbf{J}$. Saunders Redding, Arthur P. Davis and Blyden Jackson, and whose star writer was the Baldwin who admitted in letters from the journey which was meant to carry him to Africa: »I have a gloomy feeling that I won't find any answers in Africa, only more questions." Writing from Loche-les-Bainsin February, 1962, racked by guilt, but incapable of remorse, he stated: »I simply dread facing the tigerish Negro press if I return to America without having visited the land which they so abruptly are proud to claim as home. The more particularly as neither Another County nor my report on Africa is likely to please them at all. $\aleph^{3}$ 
The deeper issues of cultural identity and artistic purpose stirred by the new historical winds and the responses they elicited are conveniently capsulized in the controversy, widely publicized at the time, between Harold Cruse and Saunders Redding over the relevance to black America of the emerging Third World perspective. Printed in Presence Africaine in January, 1958, ${ }^{4}$ Cruse's article $»$ An Afro-American's Cultural View « provokingly asked: "As Negroes of Afro-American descent, and as writers, artists, creative individuals, whose culture do we develop and uphold - an Afro-American culture or an Anglo-Saxon culture?" Equating the current colonial liberation with the struggle of the Negro in America, he made a case for the autonomous existance of a distinctive black American culture which, though bearing the indelible stamp of the Negro's experience in the New World, must be defined in terms of its African origins and relation to the present day awakening of nthe colored peoples of the world «: »The American Negro cannot be understood culturally unless he is seen as a member of a detached ethnic bloc of people of African descent reared for three hundred years in the unmotherly bosom of Western civilization. « Exhorting black artists and intellectuals to abandon their traditional »Caucasian idolatry in the arts... and immature mimicry of white aesthetics« and to rehabilitate black art through a cultural renaissance analogous to the revival of indigenous cultures accompanying political nationalism in Africa, Cruse sought to establish an entirely new context and a new direction for black American artistic endeavor.

The response of J. Saunders Redding, the acknowledged dean of Negro American letters, was prompt and predictable. Addressing AMSAC's First Conference of Negro Writers in 1959, he mounted a direct attack, printed in the New Leader (May, 1960), ${ }^{5}$ against the basic conception expounded by Cruse of the American Negro minority as a people and a nation with a distinctive and autonomous cultural identity. To distinguish between an ))Afro-Americanculture « and an "AngloAmerican culture, "Redding argued, is "not only wrong but wrongheaded; The American Negro people are not a people in Cruse's sense of the word, " and to posit an analogy between African colonial liberation and the struggle of the American Negro for equal rights is tantamount to »total blindness to the truth. «In Redding's scheme, Negro culture is part and parcel of the mainstream of American experience, its folk culture - including music, dance, and vernacular speech patterns - no less than its formal literature. The latter is as intimately related to general American literature as the bough is to the branch, and the difference is »so slight that to be seen at all it must be pointed 
out." The test Redding applied to prove his point was that, with few exceptions, no work by or even about Negroes before 1950 had been widely debated because it was controversial. This was evidence, in Redding's view, that black American writing had in every period conformed to »the prevailing state of the contemporary American mind. «In this fact, too, somewhat paradoxically, is to be found the only and ssubtle distinction « between the two literatures: while sharing the nonaestheticist nature of American literary expression as well as its traditional integration of "high culture « and "popular culture elements, Negro writing is distinguished by its passive and receiving role vis-à-vis the cultural ideas and values informing it. Historically, its role has never been that of a shaping force, but of a conformer and reflector. Redding saw further corroboration of his view in the absence in Negro American history of anything resembling the Jewish reaction of Zionism to the condition of being disinherited and segregated. In fact, paradoxically, that condition has only served to intensify the Negro's »efforts as a social and literary man. . . towards validating his claim to the American heritage. « The conception which emerges from Redding's thinking is the Baldwinian one of the Negro as a historical tabula rasa whose African roots were brutally and completely severed during slavery and whose hope for an identity could only lie in »appropriating these white centuries. $\ll^{6}$ Consequently, for Redding, to speak of an identity problem for the American Negro artist is a misnomer, and to define him in an African and Third World context is both wrong and wrong-headed. As suggested in the attack on Cruse, and further elaborated in a later essay, the issue is »much less a problem of identity than of identification. $\ll^{7}$ The matter of the American Negro writer's identity was settled a long time ago. In words which in their abstract ring betray Redding's difficulty in grasping the vivifying potential of the new historical forces for black American creative expression, he depicts the African artist as living in a tribal and religious culture almost untouched by modernization. On this basis, Africa is dismissed as having no direct or immediate relevance to Negro art in America either in terms of cultural self-definition or as a source of aesthetic inspiration. For Redding, the central problem of the Negro writer was and remained that she is not permitted his identification with American culture. $\ll^{8}$

But the Trojan horse was already within the citadel. Immediately following Redding's attack on Cruse at the First Conference of Negro Writers, Samuel Allen delivered his paper entitled "Negritude and its Relevance to the American Negro Writer.« Though not directly attempting a redefinition of black American literary creativity in a Third 
World context, Allen nevertheless eloquently affirmed the useability of the African past both on the basis of African retentions in New World black culture and African-American linkages in the post-colonial situation:

In the historical light of the interaction of cultures, there is no reason why the African heritage may not be a fertile source of inspiration. It will be futile to admonish that our roots are American only, that our roots go back to the Virginian shore in 1619 and stop at the water's edge, amid the branding and the cries and trance-like intonations such as those of Cassandra when carried by Agamemnon back to Greece: "What isle, what land is this?."

Other events and coincidences conspired to remind the black literary community of the new forces at work. At the very time Redding was heading the conservative reaction to the new issues forced on the Negro by post-colonial Africa, Raisin in the Sun was playing on Broadway. Hansberry's play marked the first appearance in black American drama of an African intellectual as a major character. An equally significant symbolism, perhaps, was the fact that Asagai's main function in the play was as norm and behavior model for an emasculated Chicago Negro and his young identity seeking sister. This event was followed by the publication of Langston Hughes's anthology A $n$ African Treasury and Freedomway's special Africa issue. ${ }^{10}$ In 1959, at the Second Annual Conference of the American Society of African Culture, Harold Isaacs read his paper entitled »The American Negro and Africa. «Isaacs represented the contemporary Negro as moving »in and between parts of two worlds, « still struggling to slough off the old self-hatred stemming from internalized racist images of primitive »Poplarvilles and Tallahasses and the great host of their less visible equivalents, ${ }^{11}$ but in the process of acquiring a new self-image derived from a positive identification with modern Africa.

These initial skirmishes over the relevance of Africa and the Third World to black America did not lead to immediate and dramatic literary results. Thus, in his Introduction to A $n$ African Treasury, Langston Hughes went no further than to suggest certain similarities in the patterns of issues and reactions found in African and black American writing. In 1960, the only example of a shared racial consciousness he could detect in these writings was a common quality of »blackness in the search for roots which he felt typefied both the Harlem Renaissance and modern African art. The stage of a deeper redefinition of black American literary expression in terms of the emerging Third World perspective would only be reached in the second half of the decade. A leavening period was needed during which the new vistas which were opening up could take hold. 
As the new decade progressed, two observers showed a special affinity for the emerging African-American sensibility which in the latter half of the sixties would yield such exciting literary crops. Working within a new kind of vocabulary, John Henrik Clarke and Harold Cruse ${ }^{12}$ spoke of a new breed of American Negro, a new $»$ African-minded Afro-American, " of a black American "colony" and a black American "nationalism, « and of the "Pan-African « perspectives in the Negro's situation. By 1962 , the contours of a new consciousness were crystallizing with suffi, cient clarity for Cruse to feel justified in assigning to it a label of its own: »a new set of political and cultural values which, taken together, have come to be called 'Afro-Americanism'. "The specific thrusts behind this ))Afro-Americanism, Cruse argued, were the sense of a lag in the progress of American blacks towards freedom compared to the advances made in the colonial world and the sharpened feeling of isolation and alienation in the West. Also, the colonial metaphor offered the black American by Africa as a descriptive model applicable to the American situation stimulated the awareness of a shared condition. Distinguishable from previous ideological patterns in Negro history by its hostility or scepticism toward NAACP's legalism, white liberals, Marxist groups, and the exclusiveness of the Muslims, the temper of the new "AfroAmerican« outlook could best be guaged, Cruse felt, by looking at its "pantheon of modem heroes«: Carnus, Lumumba, Nkrumah, Sekou Touré, Castro, Mao Tse-tung, Robert Williams and Malcolm X. In Cruse's pantheon, black Americans joined hands with Africa, Asia and the Caribbean in their common historical revolt, "For those who adopt it, « he concluded, ))Afro-Americanismserves the purpose of placing them in close rapport with the content and spirit of the world revolution. «

Such were the new vistas whose leavening impact was at work in the first half of the decade. Not until the crise de conscience of the mid-sixties, however, did they come to fruition as a basis for literary creativity. Traditional Negro confidence in white liberal ideals was severely shaken after 1965, as was the belief in the efficacy of American democratic institutions in integrating not just deserving individuals, but the black masses. In the ensuing intellectual and ideological vacuum, a radicalization of black literary thought occurred which stimulated separatist ideas. This development was not without precedent in black American history. What was different for literary intellectuals this time, however, was the geopolitical context of a black American cultural revival. The literary scene was ripe for an influx of the ideas which had been incubating for some time and whose implications for black literary expression 
World context, Allen nevertheless eloquently affirmed the useability of the African past both on the basis of African retentions in New World black culture and African-American linkages in the post-colonial situation:

In the historical light of the interaction of cultures, there is no reason why the African heritage may not be a fertile source of inspiration. It will be futile to admonish that our roots are American only, that our roots go back to the Virginian shore in 1619 and stop at the water's edge, amid the branding and the cries and trance-like intonations such as those of Cassandra when carried by Agamemnon back to Greece: "What isle, what land is this?."

Other events and coincidences conspired to remind the black literary community of the new forces at work. At the very time Redding was heading the conservative reaction to the new issues forced on the Negro by post-colonial Africa, Raisin in the Sun was playing on Broadway. Hansberry's play marked the first appearance in black American drama of an African intellectual as a major character. An equally significant symbolism, perhaps, was the fact that Asagai's main function in the play was as norm and behavior model for an emasculated Chicago Negro and his young identity seeking sister. This event was followed by the publication of Langston Hughes's anthology A $n$ African Treasury and Freedomway's special Africa issue. ${ }^{10}$ In 1959, at the Second Annual Conference of the American Society of African Culture, Harold Isaacs read his paper entitled »The American Negro and Africa. «Isaacs represented the contemporary Negro as moving sin and between parts of two worlds, « still struggling to slough off the old self-hatred stemming from internalized racist images of primitive »Poplarvilles and Tallahasses and the great host of their less visible equivalents, $\aleph^{11}$ but in the process of acquiring a new self-image derived from a positive identification with modem Africa.

These initial skirmishes over the relevance of Africa and the Third World to black America did not lead to immediate and dramatic literary results. Thus, in his Introduction to A $n$ African Treasury, Langston Hughes went no further than to suggest certain similarities in the patterns of issues and reactions found in African and black American writing. In 1960, the only example of a shared racial consciousness he could detect in these writings was a common quality of »blackness « in the search for roots which he felt typefied both the Harlem Renaissance and modem African art. The stage of a deeper redefinition of black American literary expression in terms of the emerging Third World perspective would only be reached in the second half of the decade. A leavening period was needed during which the new vistas which were opening up could take hold. 
As the new decade progressed, two observers showed a special affinity for the emerging African-American sensibility which in the latter half of the sixties would yield such exciting literary crops. Working within a new kind of vocabulary, John Henrik Clarke and Harold Cruse ${ }^{12}$ spoke of a new breed of American Negro, a new ))African-mindedAfro-American, « of a black American »colony« and a black American »nationalism, " and of the "Pan-African « perspectives in the Negro's situation. By 1962 , the contours of a new consciousness were crystallizing with sufficient clarity for Cruse to feel justified in assigning to it a label of its own: "a new set of political and cultural values which, taken together, have come to be called 'Afro-Americanism'. « The specific thrusts behind this "Afro-Americanism, "Cruse argued, were the sense of a lag in the progress of American blacks towards freedom compared to the advances made in the colonial world and the sharpened feeling of isolation and alienation in the West. Also, the colonial metaphor offered the black American by Africa as a descriptive model applicable to the American situation stimulated the awareness of a shared condition. Distinguishable from previous ideological patterns in Negro history by its hostility or scepticism toward NAACP's legalism, white liberals, Marxist groups, and the exclusiveness of the Muslims, the temper of the new "AfroAmerican« outlook could best be guaged, Cruse felt, by looking at its "pantheon of modem heroes«: Camus, Lumumba, Nkrumah, Sekou Touré, Castro, Mao Tse-tung, Robert Williams and Malcolm X. In Cruse's pantheon, black Americans joined hands with Africa, Asia and the Caribbean in their common historical revolt. "For those who adopt it, " he concluded, ))Afro-Americanismserves the purpose of placing them in close rapport with the content and spirit of the world revolution. «

Such were the new vistas whose leavening impact was at work in the first half of the decade. Not until the crise de conscience of the mid-sixties, however, did they come to fruition as a basis for literary creativity. Traditional Negro confidence in white liberal ideals was severely shaken after 1965, as was the belief in the efficacy of American democratic institutions in integrating not just deserving individuals, but the black masses. In the ensuing intellectual and ideological vacuum, a radicalization of black literary thought occurred which stimulated separatist ideas. This development was not without precedent in black American history. What was different for literary intellectuals this time, however, was the geopolitical context of a black American cultural revival. The literary scene was ripe for an influx of the ideas which had been incubating for some time and whose implications for black literary expression 
had been a major concern of the Négritude movement and Présence Africaine in the whole post-war period.

The writings of black American literary intellectuals in the second half of the decade abundantly reflect their preoccupation with this crisis of consciousness and sensibility leading to identification with an Afrocentric Third World. Their statements were often aglow with the joy of observing the ancestral continent emerge from obscurity on to the global historical arena. In The New Black Poetry, perhaps the most significant anthology of black American verse to come out of the sixties, Clarence Major's preface spoke of $»$ the inner crisis of black reality, ${ }^{13}$ while Stephen Henderson commented in the apocalyptic rhetoric of the times on the "profound revolution . . . in the minds of black people" which, when completed, will have turned »Negroes « into »black people, « transforming or destroying America in the process. Another characteristic expression of their shared experience of crisis and reorientation is found in Sonia Sanchez's preface to We Be Word Scorcerers, ${ }^{15}$ an anthology of fiction by twenty-five black American writers of the late sixties. According to the editor's claim, each of the contributors »was born a Negro with no knowledge of himself or history. Each one of us was the finished product of an American dream, nightmarish in concept and execution. Each one of us has survived to begin our journey toward »Blackness. «In the works of these and other writers, the literary journey to »Blackness« followed a variety of routes. Nikki Giovanni's took her from her youthful position as »Ayan Rand-Barry Goldwater all the way ${ }^{16}$ to that of reigning poetess of the Black Arts Movement. Baraka went from Rutgers and Howard, the U.S. Air Force, and Greenwich Village to revolutionary writing and politics in Harlem, Newark, and Africa. Yet another pattern is reflected in William Melvin Kelley's career as he moved from the exclusive Fieldstone school and the Harvard English Department to committed racial fiction and residence in Africa and the West Indies.

Animating all these literary odysseys from "Negroness « to »Blackness, " was a shared impulse to move beyond the first post-war vision of the black man as America's metaphor and to free Afro-America and her art from the shackles of a declining and antihumanistic civilization by seeking a new anchorage in historically ascending cultures. Major saw his collection of black verse as rooted in a spirituality and a historical sense reaching back beyond Jamestown to the parent continent. In this perspective, the black man's New World experience dwindles in significance to a relatively minor episode whose chief event, Emanicipation, is an important reference point only in the white man's 
fantasy world. In Henderson's vision, William K. Kgositsile - a black American born in South Africa - appeared as a symbol of the new African-American imaginative world and of a Pan-African literary synthesis spanning both hemispheres. In a passage quoted by Henderson, he expressed this new bi-continental literary sensibility in lyrical prose:

There is nothing like art - in the oppressor's sense of art. There is only movement. Force. Creative power. The walk of Sophiatown tsotsi or my Harlem brother on Lenox Avenue. Field hollers. The Blues. A Tane riff. Marvin Gaye or mbaqanga. Anguished happiness. Creative power, in whatever form it is released, moves like the dancer's muscles.

But the impulse is personal. ${ }^{17}$

One specific effect of this Afro-centric thought on black American writing may be observed in its impact on the classic pattern of rage and celebration. In the pre-Civil war period, this duality of expressive modes is found in black abolitionist oratory, slave narratives, and, on the other hand, in a rich crop of black jokelore and folk tales. At the turn of the century, the same twin impulse may be found embodied in Paul Laurence Dunbar's The Sport of the Gods (1902) and in Charles Chesnutt's The Conjure Woman (1899). The former is simultaneously a chronicle of the disintegration of a rural black family in the big city and a story of the making of the ghetto, whose bitterness is communicated through the conventions of contemporary naturalistic fiction, as suggested by the title. Chesnutt's sequence of Uncle Julius tales, on the other hand, made extensive use of folk materials to celebrate the resilience and resourcefulness of black folk. Using irony to circumvent the racist stereotypes demanded by white publishers and readers Chesnutt made his story-telling hero a figure revelling in his blackness and ways of "puttin' on ole massa. "In the literature of the Harlem Renaissance the same duality appears with almost schematic neatness in the work of Claude McKay and Jean Toomer. The sonnets of McKay, the Jamaica-born »black Prometheus" (Nathan Huggins in Harlem Renaissance) whose personal friends included Max Eastman, Floyd Dell, John Reed, and Marcus Garvey, may not have contributed much in the way of technical innovation, but Harlem Shadows (1922) did stake out new territory for this time-honored poetic form by the racial and social commitment and violent language of several of its pieces. Conversely, Cane was an incantatory celebration of a uniquely black ethos. Through figures of redemptive black womanhood (Fern, Karintha) and the preacher-prophet Barlo, »a clean-muscled, magnificent black-skinned Negro « whose vision of the rise of the »big and black and powerful « African ancestor of all New World blacks inspires supernatural events in the Southern town, Toomer mythologized the sensibility of the black folk of Georgia's »Dixie 
Pikes in a spirit of racial pride. Finally, post-Renaissance writing may be accommodated within the same historical duality.The Great Depression hit the black community hardest of all, arousing literary anger to a pitch unsurpassed up to that point in the early work of Richard Wright. The anti-hero of Native Son was a confrontation with the accumulated damage inflicted on the black man in America and a release of phobias, anxieties, and aggressions. Following this outburst of anger, a spirit of celebration became the dominant mood as a new literary generation, headed by James Baldwin and Ralph Ellison, emerged in the early fifties. The peculiar achievement of this generation was to reinterpret the racial experience in the light of post-war existential ideas so as to assign to that experience a priestly and redemptive role in a war-battered and crisis-conscious Western culture.

In black American writing of the sixties, this duality persisted, but its meaning changed. The change is reflected in the imagery created by a new generation to express the role of the racial artist. Seeing the poetry of the period as permeated by a twin impulse to "murder and create, " Eugene Redmond has described the poetic field as a spectacle of "festivals and funerals. $\ll^{18}$ In the same spirit, Henderson praised Kgositsile's poems as a body of work whose voice "speaks thunders. . . or sings with liquid fire, $\ll^{19}$ and in the introduction to his anthology Clarence Major described the poems assembled as simultaneously»death cries« to a capitalistic and racist West and ssolar concerts to the infinite tacit incantations of our elegance, as we are, as we long to be. Black radiance. «In the many neologisms coined to express the artist's vocation, scattered throughout black writing of the late sixties, the same duality appears. One cluster includes such words as »warrior, « »fighter, « »soldier, " »machine gunner, « »assassin, $a$ »hunter, «))desecratoß while in the other are found designations of the writer as "necromancer, «»neo-hoodoo soothsayer, « »conjurer, « »magician, « »wizard, « »babalawo, « »shaikh, « "griot, « »shaman, « »sorcerer, « »exorcist, « ))enchanter» and "oracle." Drawn from Third World anti-colonial politics and African tribal backgrounds, such imagery served the purpose of de-Westernizing black American aesthetic thought. At the same time, it was a reenactment of a classic duality in the literary expression of New World blacks.

As the decade progressed, a new generation subjected the accustomed meaning and function of literary anger to severe critical scrutiny. Increasingly, writers abjured traditional protest, finding it corrupted by illusions and false assumptions which they felt invalidated it as a viable mode. In a representative essay entitled $»$ The New Black Literature, $\iota^{20}$ Hoyt Fuller argued that moral evasion is at the core of the protest genre. 
Western civilization must find some way of assuaging the guilt imposed by its monstrous crimes in our century. In the American context, whites face an imputation of guilt in the very facts of black life. One strategy devised to avoid admission of complicity is manipulation and control of the definition of black literary expression by labelling it "protest literature." In this way, Afro-American literature may be dismissed, placed in a special category on the periphery of art. This assignment of the black writer to a special province or "ghetto « of literary creation demonstrates the determination of the white majority culture to prevent the minority artist from moving into a position where he can project his own personal and group symbols. Obsessed with controlling this literature in order to relieve their fears and guilt feelings, whites have fashioned a protest formula for use by blacks with ready-made prescriptions for characterization, theme, and plot. It was this formula, with its sinister implications, that Cecil Brown, himself one of the neo-black novelists, described in the fiery rhetorical style of the period as based on the preconceived picture of »a raging, ferocious, uncool, demoralized black boy banging on the immaculate door of White Society, begging, not so much for political justice as for his own identity, and in the process of consuming himself, so that in the final analysis, his destiny is at the mercy of the White Man. $\ll^{21}$

To such indictments of protest on psychological and moral grounds was added the disillusionment caused by Euro-American neo-colonialism and the white backlash on the home front. Implicit in the genre had always been the assumption that the white world has a conscience, however, dormant or torpid, to which it is possible to appeal. Protest literature had further assumed that the ideals and principles upon which the nation is built are sound and that, therefore, integration of black America into the mainstream culture is a desirable goal. Consequently, the protest writer had conceived of himself as an advocate of his people's rights and as an ambassador for their history and culture vis-à-vis whites in order to prove them worthy of admission. He had even at times felt called upon to act as the defender of American ideals and'human rights when whites appeared to be corrupting them. In the second half of the decade, this traditional basis of protest writing foundered as the old trust yielded to a sense of the white world's malignancy, reflected in the widespread use of a rhetoric representing America as the „Fourth Reich, " guilty of "genocide" and seeking a "final solution« to the race problem, and whose penitentiaries are »gas chambers« and »concentration camps, « a society policed by »fascist « state troopers and whose proper spelling is "Amerika."To such a view, the old protest tradition could 
only be worse than useless, failing as it had always done to take account of the fundamental facts of white moral evasion and racist use of power.

This, then, was the new climate of thought and feeling for which the sensibility of anger sought to shape proper modes of expression, a vision of a world of malevolent aggression directed against the black race and threatening the survival of humanist ideals. What was felt to be required was a literature stripped of the illusory old idealisms and hopes for an egalitarian and colorblind society in the New World, a literature in which anger would not mean frustration, bitterness, and pleading, but a heroic and affirmative wrath. In a world in which the prime issues are survival and liberation, the literary artist must rise with the rest of the oppressed nation to seize control and power. Literary creation is verbal warfare and part of the revolutionary battle against the colonist now being waged for the minds of black people in preparation for the coming Armageddon. The new literature of anger was not to be written out of frustration and wailing, nor was its purpose to be apology. It was to be a literature devoted to demystifying white power and simultaneously created out of a newfound personal and collective black power. Informed by a new cynicism, angry black writers in the sixties started from a vision of ruthless anti-black forces at work in their American and Westem environment, but also from a breathtaking sense of being in league with the rising, post-Westem civilizations.

Turning away from his traditional white liberal audience, the black writer increasingly addressed his own racial community, joining in this struggle to survive and renovate itself socially and morally. Deflected from its previous outlet in protest art, anger fashioned new uses for itself in artistic modes and stances expressed in Third World imagery. Frequently, the racial writer was defined as a freedom fighter or artist-warrior whose creative labors are "survival motions" and acts of anti-colonial liberation. Works of art would be metaphorically described as ,daggers, " »bullets, " "fists, " »teeth, " or potent "poisons, " operating directly and concretely in the world to destroy the hold of the oppressor on the black mind. This strategy went far beyond the efforts of preceding generations to control the racial iconography by creating, in the words of James Weldon Johnson from 1922, »symbols from within. $*^{22}$ The concern of the post-1965 generation was "the deliberate desecration and smashing of idols, the turning inside out of symbols, to which black writers are now proceding with a vengeance. $2^{23}$ As an example of this kind of ritual killing or »desecration « of the oppressor's cultural images may be used Carolyne G. Gerald's poem, which is a savage defamation and literary lynching of the cherished mythical figure of the muse: 
Dress the muse in black. . .

No!

Kill her!

Make her jump

Burning bright white bitch

From the pitched peaks of our houses

Let her shriek

Pale old faded biddy. . .

Hear her?

Stomping her feet round

On our rooftops all these years?

And we, inside. Yassuh meek

Warming our hands by the fire (like sheep)

Phony 'fay!

Look at her;

Running past

Blond flames waving in the wind

Blow on her!

Grab a torch up in your hand and come outside

And watch her burn

And crackle

And topple

And lie

Fallen

Off our rooftops

Into the flame

Looks up

And gather round

And shake your torch up at her!

Tease her like a yellow cat

Crouching on the rook

Make her jump

Make her howl

Make her yowl

Falling in the fire

Make it hot. . .

Make it hate

Clap and stomp round the fire

And shout the spirit oit of her.

And draw your circle close

For we'll kill us a devil tonight. 
Come on away, now!

Now!

We'll find our own saint

(or another name for her)

No need for hell's fire now

The fire's weak

And burned out

The universe is black again. ${ }^{24}$

Thus was fought the literary battle against the colonial master's power as exercised through his control of the language. The special province of anger within the greater war waged by the race should no longer be apology or pleading, but confrontation and attack in order to appropriate the linguistic medium, demystify the white enemy, diagnose the damage done to the black race in America, educate and exhort. A cleansing of the language was felt to be imperative to enable the artist to regenerate the racial group. A soldier in the war against the colonial controllers of language, engaged in the service of his race and the AfroAmerican nation, the black writer was now to channel his rage into other outlets than the traditional novels and poems of moral outcry. A new combative image, drawn from Third World national liberation struggles, increasingly replaced that of the »Negro « protest artist. In this new image there was no room for the traditional social moralism. In a white world felt to be without conscience, its spirit must be martial and its expression military.

Similarly, the celebrative pattern responded to the pressures of the times. Previous eulogies in literature of the Negro's heritage had usually been motivated by a desire to affirm his ultimate Americanness. Even as Toomer, for example, erected his racial mythos in Cane, he viewed it in the context of America's passage from a rural to an urban order. The Southern Negro's culture is related to the quintessentially rural which alone has saving power in a modern American wasteland. Adopted for literary use by Baldwin and Ellison a generation later, the Negro's Negroness was invested with a meta-racial redemptive meaning in contemporary America. Their two symbolic figures - the black stranger in the Euro-American village and the invisible underground man in the big American city - appear as magnified Americans and exaggerated modems whose role in our age is a priestly one. A similar notion persisted in the early thought of Amiri Baraka. After paying tribute to surviving Africanisms in religion, music, and folklore in »Myth of a 'Negro Literature') $(1962)^{25}$, he proceeded to define the distinctive features of Negro culture in much the same terms as the preceding generation, i.e. 
as a heightened version of the American experience. The Negro is the archetypal American, his experience is sevidence of a more profound America" whose accumulated black wisdom and long stewardship in suffering have a redemptive value. To celebrate this black and American wisdom is, properly speaking, the business of Negro art.

As the sixties progressed, however, Baraka's generation underwent the conversion to »Blackness « which altered the basis for artistic celebration of the racial heritage. For the "more profound America« were substituted the concept of an autonomous Afro-American nation and an exclusive diasporic and anti-Western identity. Whereas to preceding generations, the Negro's »double consciousness« had been his unique resource, to Baraka's young contemporaries it became the primary symptom of his malady. In their writings, derogatory references to DuBois's idea were frequent, even as they embraced him and included him in their pantheon of heroes. Instead was projected the ideal of a unified non-Western sensibility, merging ideas of a distinctive and peculiar racial Geist, a separate culture, and a Black Nation.

Music and its lexicon were of great importance in redefining and expressing the celebrative impulse in the new Afro-American writing. Negatively, this was done by opposing the symphony and the symphony orchestra to jazz and the jazz band in order to convey the sense of two incompatible cultures and the aesthetic modes derived from them. Turned into symbolic microcosms, symphonic music and the manner of its performance became mirrors of the anti-humanism of Western art and the destructive intellectual and social values sustaining it. In an essay characteristic of the period, Ortiz M. Walton ${ }^{26}$ equated the symphony orchestra with three other and analogous products of Western societies: the industrial plant, the machine, and political autocracy. The invention of the symphony orchestra is perceived as an event symbolizing »the complete rationalization of music, « including attendant developments of specialization, rigid divisions and hierarchies. Its functioning is structurally parallel to »an assembly-line operation. . . organized along lines of maximal efficiency, « making no allowance for individual deviations or audience participation, and rigidly controlled by a ))foreman or conductor" whose technical know-how secures "the normal functioning of the machine. «Its underlying principle is an ideal of perfect rational order, a static structure fixed through notation, and rehearsed mechanically. At base it is a totalitarian system: »The symphony . . . is a dictatorship. There is a rigidity of form and craft practice a virtual enslavement of the individual to the autocratic conductor." Thus the proudest product of Western musical achievement was turned 
into a symbolic reflection of a repressive and antihumanistic aesthetic.

Against this conception of art were pitted the principles of aesthetic creation governing black music, seen as African survivals largely untouched by the hegemony of the slave master's culture. Those elements of the African heritage which did not have artifacts as their end products, i.e. religion, dance, and music, eluded white control and remained in many respects intact. Hence black musical expression is of a different order and inherently at odds with the Western tradition. Rooted in a sensibility whose apprehension of reality is based on an understanding of time as perpetual flow, Afro-American music is fundamentally »improvisational « and »non-matrixed. «In order to be faithful to its innermost nature, this music must, like all black art, conceive of itself as movement: »Art goes. Art is not fixed. Art can not be fixed. Art is change, like music, poetry, and writing are, when conceived. $\ll^{27}$ Refusing to move against time or to arrest and fix reality in static structures, it fearlessly embraces flux and motion. Perceiving fluctuation not as chaos, but as the creative principle of the universe, it is not concerned to impose order or system. Increasingly, black American music came to be viewed as the embodiment of non-white, non-Western "continuous repository of black consciousness, $* r^{28}$ closely related to an ethic of action and immediacy with a high valuation on affective behavior, a collective art, geared to communal experience and celebrative affirmation of the racial group. The musician was no longer seen as an arch-American or arch-modern whose priestly office is to exorcise chaos, but as »the reemerging African ${ }^{29}$ in black American culture, a vatic figure whose performances are ritual ceremonials of the Afro-American nation. He is a pioneer in the expression of true black sensibility, creating and recreating in his art his own and his people's negritude. The artistic process in which he is involved is analogous to the African custom of building temples and statues of mud, which are washed away by the rains, and then rebuilt. Similarly the music of Afro-America is a perishable art, traditionally preserved and communicated through perpetual creation and recreation.

The importance of this musical tradition as model and exemplar for black celebrative self-expression in literature is hard to overestimate. Its relationship to both the verbal and the visual arts was seen as symbiotic, the same freely expressive styles operating in Afro-American writing, painting and music alike. Thus to the poet Lance Jeffers the interchangeability of »pen « and »horn $\aleph^{30}$ was as natural as was the AfricanAmerican literary-musical analogy to Ishmael Reed in the creative life 
of his writer-hero Quickskill: his "writing was his Hoodoo. . . his typewriter was his drum he danced to. $\aleph^{31}$

The impact of this African-American musical aesthetic on the young literary celebrants may be specifically observed in the tendency to view the poem, fiction, or play as analogous to the non-matrixed, swinging movements of jazz, the sophisticated »scream « of the native African, the field holler of the black American slave, and the soul shouts of James Brown. It further underlies the frequent metaphorical representation of black literary works as force, energy, »solar concerts, " or »black radiance, " as these works embody heroic black lives or the Black Nation as actually existing or as conceived at a later, more fully realized stage. Finally, it is reflected in the tendency to remove all hierarchical distinctions between art and life, and between artist, work, and audience. The literary rhetoric of the sixties abounds in semi-mystical statements of black people being the poets and the audience as well as the poems. The writer-singer of black beauty merges with the song and the racial audience in a totality of expression which partakes of the nature of litanies and incantations in the celebration of black American and panAfrican peoplehood and force vitale. No longer an affirmer of the Negro's Americanness, the black literary artist is the celebrator of a unique racial genius, offering in his work heightened glimpses of the black Geist fulfilled. He serves his people, guarding and preserving its historical memory. He is the miracle worker, the creator of symbols and the singer of heroes, "working his juju with the word on the world. $\ll^{32}$ In this way, while continuing the celebrative mode, black writers in the sixties radically transformed its meaning and purpose. In singing the praise of Afro-American nationhood and the primordial emotiveness of black people, they sought to join in the adventure of shaping a post-American and post-Western humanism which they saw being born into the world in our time.

Thus come together the strands in the design we have attempted to establish in the new black writing of the nineteen-sixties: a reenactment of the traditional pattern of rage and celebration within an Afrocentric Third World framework. Whether their art were wrath-filled ritual destructions of sthe white thing « or joyful homages to soul and peoplehood, black writers saw themselves as being about the historical task of de-Westernizing their culture in preparation for a new era of "afterwhiteness color. «Toward this end black literary creativity must be directed and made functional. Whether as »desecrators« or »necromancers, « they responded to a shared awareness of living in new patterns of 
history. In the endeavor to express that awareness in terms drawn from their New World experience, they found the deepest meaning of their art.

\section{NOTES}

1. Samuel W. Allen, »Negritude and its Relevance to the American Negro Writer, « in Cavalcade, eds. Arthur P. Davis and Saunders Redding (Boston: Houghton Mifflin Company, 1971), p. 618. Allen's essay was initially written in 1958-1959 and presented as a paper at the First Conference of Negro Writers in 1959.

2. $I b z d$, p. 618.

3. James Baldwin, »Letters from a Journey, «Black Vozces, ed. Herbert Hill (London: Elek Books, 1964), p. 42, 47.

4. Reprinted in Cruse's collection of essays Rebellzon or Revolutzon (New York: William Morrow \& Company, 1968).

5. Entitled "Negro Writing in America."

6. Baldwin, »Autobiographical Notes, «Notes of a Native Son (New York: Bantam Books, 1964), p. 4.

7. "The Problems of the Negro Writer, « in Black and White in Amerzcan Culture, eds. Jules Chametzky and Sidney Kaplan (New York: The Viking Press, 1969), pp. 360-361. Originally published in The Massachusetts Review, Vol. VI (1964-1965).

8. Ibid., p. 363.

9. Cavalcade, p. 625.

10. Langston Hughes, ed., An African Treasury (New York: Pyramid Books, 1961).

Freedomways, Vol. II, No. 4(1962).

11. Harold Isaacs, "The American Negro and Africa: "Some Notes, «Phylon, Vol. XX (1959), p. 220.

12. The following quotations are from Clarke's $»$ The New Afro-American Nationalism,. Freedomways, Vol. I (1961), pp. 285-295, and Cruse's »Negro Nationalism(* New Wave, « collected in Rebellion or Revolution (originally published 1962).

13. Clarence Major, ed., The New Black Poetry (New York: International Publishers, 1969).

14. Mercer Cook and Stephen E. Henderson, The Black Militant Wrzter in Afrzca and the Unzted States (Madison: The University of Wisconsin Press, 1969), p. 67.

15. Sonia Sanchez, ed., We Be Word Sorcerers (New York: Bantam, 1973).

16. Gemini (New York: The Viking Press, 1971), p. 34.

17. The Black Mzlitant Wrzter in Afrzca and the Unzted States, p. 118.

18. Drumvoices The Mission of Afro-American Poetry, (Garden City, New York: Doubleday, 1976), Chapter VI.

19. The Black Mzlztant Writer in Afrzca and the Unzted States, p. 118.

20. In The Black Aesthetzc, ed. Addison Gayle,Jr. (New York: Doubleday \& Company), pp. 327-348.

21. Cited by Fuller, idib., p. 346.

22. James Weldon Johnson, ed., The Book of American Negro Poetry (New York: Harcourt, Brace \& World, Inc., 1922), p. 41.

23. Carolyne G. Gerald, "The Black Writer and His Role, "The Black Aesthetzc, pp. 354-355. Originally published 1969.

24. Ibid, p. 355-356.

25. Home (New York: William Morrow \& Co., 1966). 
26. Ortiz M. Walton, "A Comparative Analysis of the African and the Western Aesthetics,((The Black Aesthetic, pp. 154-164.

All quotations from this essay.

27. James T. Stewart, »The Development of the Black RevolutionaryArtist, «Black Fire, eds. LeRoi Jones and Larry Neal (New York: William Morrow, 1968), pp. 4-5.

28. Ron Wellburn, »The Black Aesthetic Imperative,(( The Black Aesthetic, p. 126.

29. Kimberly W. Benston, The Renegade and the Mask (New Haven and London: Yale University Press, 1976), p. 89.

30, "Afroamerican Literature: The Conscience of Man, «New Black Voices, ed. Abraham Chapman (New York and Toronto: New American Library, 1972), p. 506. Originally published 1971.

31. Flight to Canada (New York: Random House, 1976), p. 89.

32. Larry Neal, "And Shine Swam On, «Black Fire, p. 655.

33. Amiri Baraka, RAISE RACE RAYS RAZE (New York: Random House, 1972), p. 34. Originally published 1967. 